\title{
Perubahan warna basis akrilik setelah penggunaan pasta pembersih gigitiruan rosella (The changes of acrylic base color after using roselle pasta denture cleanser)
}

\author{
${ }^{1}$ Evan G. Tunggal, ${ }^{2}$ Moh. Dharmautama, ${ }^{2}$ Eri H. Jubhari \\ ${ }^{1}$ Program Pendidikan Dokter Gigi Spesialis Prostodonsia \\ ${ }^{2}$ Bagian Prostodonsia \\ Fakultas Kedokteran Gigi, Universitas Hasanuddin \\ Makassar, Indonesia
}

\begin{abstract}
This clinical experimental study was aimed to determine the effect of roselle denture cleanser paste usage on acrylic base color degradation. Acrylic base color degradation was assessed by providing roselle denture cleanser to 5 subjects to be used every day. In month 3, 6 and 9, data collection were performed by a professional photographer and assessed by CIELab system. Data were analyzed using Wilcoxon and friedman two ways. Acrylic base color, before and after pasta using, showed a statistically significant difference in the $6^{\text {th }}$ and $9^{\text {th }}$ month. In conclusion, acrylic base color changes after using of pasta for 9 months.
\end{abstract}

Keywords: roselle paste, denture cleanser, acrylic base, color degradation

\begin{abstract}
ABSTRAK
Penelitian ini bertujuan untuk mengetahui pengaruh penggunaan pasta pembersih gigitiruan rosella terhadap degradasi warna basis gigitiruan akrilik. Pada penelitian eksperimen klinis ini, 5 orang pemakai gigitiruan penuh akrilik diberikan pasta pembersih rosella untuk dipakai setiap hari. Pada bulan ke-3, 6 dan 9 dilakukan pengambilan data oleh seorang fotografer profesional dan penilaian warna dengan sistem CIELab. Data dianalisis secara statistik dengan uji Wilcoxon dan related sample friedman two ways. Hasil menunjukkan terjadi perubahan warna basis akrilik yang bermakna secara statistik setelah pemakaian pasta selama 6 dan 9 bulan. Disimpulkan bahwa terjadi perubahan warna basis akrilik setelah pemakaian pasta selama 9 bulan.
\end{abstract}

Kata kunci: pasta rosella, pembersih gigitiruan, basis akrilik, degradasi warna

Koresponden: Evan G. Tunggal.E-mail: evangunawantunggal@gmail.com

\section{PENDAHULUAN}

Kehilangan gigi sebagian bahkan seluruhnya, tidak hanya dialami oleh mereka yang berusia lanjut, tetapijuga oleh mereka yang berusiajauh lebih muda. Banyakhal yang dapatmenyebabkan kehilangan gigi; tapi karies gigi dan penyakit periodontal dipandang sebagai dua faktor utama penyebab kejadian ini.

Tersedia banyak jenis pilihan gigi tiruan untuk menggantikan gigi yang hilang, mulai dari gigi tiruan lepasan hingga gigi tiruan cekat. Gigi tiruan lepasan konvensional berbahan akrilik polimerisasi panas masih umum dipilih. ${ }^{1}$ Gigi tiruan jenis ini, disamping memiliki sejumlah keuntungan yang membuatnya tetap menjadi pilihan sampai saat ini, juga memiliki kekurangan. Permukaan akrilik yang menghadap jaringan mukosa atau intaglio, biasanya memiliki pit dan porositas mikro yang dapat menjadi tempat akumulasi organisma mikro. Akumulasi organism mikro ini sulit dibersihkan dan dikenal sebagai plak gigi tiruan $^{2}$

Plak gigi tiruan merupakan lapisan organisma mikro, yang hasil metabolismanya bersifat heterogen yaitu meliputi $10^{11}$ organisma/g. Tahap pembentukan plak gigi tiruan dimulai dari perlekatan, agregasi dan pertumbuhan mikroba. Akumulasi plak umumnya terjadi pada daerah yang terlindungi dari aliran saliva dan gaya mekanis yang dapat membersihkannya di dalam mulut. Gigi tiruan akrilik ternyata mendukung lingkungan seperti ini. ${ }^{3}$

Flora mikro yang dapat dikultur dari plak pada gigi tiruan adalah Streptococcus spp. (S.sanguinis, utamanya S.oralis, S.anginosus, dan S.salivarius), Staphylococcus spp. (S.aureus, dan S.epidermidis), bakteri Gram-positif berbentuk batang Actinomyces spp. (A.israelii, A.naeslundii, dan A.odontolyticus), laktobasilus, Propionibacterium spp, Veillonella spp, bakteri Gram-negatif berbentuk batang dan Candida albicans. Tidakditemukannya Streptococcus mutans sebagai spesis mikroba dominan dalam plak gigi tiruan merupakan petanda penting karena bakteri ini merupakan bakteri yang dominan pada plak dental, dan dihubungkan dengan karies gigi. ${ }^{3}$

Masalah yang dapat timbul akibat akumulasi plak gigi tiruan adalah stomatitis gigi tiruan, oral malodour, infeksi, dan masalah higienitas. ${ }^{3}$ Atas dasar tersebut, pembersihan gigi tiruan harus diperhatikan. Dua cara pembersihan yang umum dilakukan adalah teknik mekanik dan teknik kimiawi. Pembersihan gigi tiruan secara mekanis menggunakan sikat gigi dan teknik ultrasonik. Pembersihan secara kimiawi dilakukan dengan merendam gigi tiruan dalam larutan desinfektan, seperti klorheksidin, alkali peroksida, 
alkali hipoklorit, sodiumhipoklorit, enzim, dan bahan herbal. ${ }^{4}$

Salah satu bahan herbal yang banyak digunakan dalambidang kedokteran tradisional adalah tanaman rosella (Hibiscus sabdariffa L.). Penggunaan bunga rosella sebagai minuman kesehatan banyak dilakukan oleh masyarakat Indonesia. Daun atau kelopak bunga yang direbus dengan air, berkhasiat sebagai peluruh kencing dan merangsang keluarnya empedu dari hati, menurunkan tekanan darah, mengurangi kekentalan darah, dan meningkatkan peristaltik usus. Khasiat lain dari tanaman rosellayang telah diketahui sebagai antikejang, untuk pengobatan cacingan, dan sebagai antibakteri. $^{5}$

Terdapat sejumlah macam bakteri yang masih sensitif dengan tumbuhan rosella, yaitu Bacillus spp., dan S.aureus. ${ }^{6}$ Selain itu, tanaman rosella juga telah diketahui efektif sebagai antifungi. Hasil sejumlah studitelah membuktikan bahwa ekstrak bunga rosella mampu menghambat pertumbuhan C.albican yang merupakan salah satu mikroorganisme penyusun plak pada gigitiruan. Suatu penelitian yang dilakukan oleh Maruapey menunjukkan bahwa pasta pembersih gigi tiruan yang bahan dasarnya bunga rosella efektif menghambat pembentukan plak, serta pertumbuhan bakteri dan C.albican. ${ }^{4}$

Selain itu, rosella juga mengandung antosianin yang memberikan warna merah yang keunguan pada bunga rosella. Adanya zat warna ini menyebabkan rosella sering dijadikan bahan pewarna alami. Basis akrilik memiliki porositas dan cenderung menyerap air. Akan tetapi sejumlah peneliti telah menunjukkan bahwa pemakaian ekstrak rosella sebagai pembersih gigi tiruan tidak menyebabkan terjadinya degradasi warna akrilik. Meskipun demikian, efek pemakaian pasta pembersih rosella dalam waktu yang relatif lama, belum pernah dilaporkan. Hal ini mungkin dapat menyebabkan terjadinya degradasi warna basis gigi tiruan akrilik.

Hal tersebut yang melatar belakangi penelitian dilakukan, yaitu untuk mengetahui adanya pengaruh penggunaan pasta pembersih gigi tiruan akrilik dari bahan rosella terhadap degradasi warna basis akrilik dalam jangka waktu yang lama.

\section{BAHAN DAN METODE}

Penelitian ini merupakan penelitian eksperimen klinis dan laboratorium, dengan desain pre and post test melibatkan lima orang sampel (ethical clearance dari Komite Etik Penelitian Kedokteran Universitas Hasanuddin No.UH14020076). Sampel penelitian adalah pengguna gigi tiruan lengkap (GTL) akrilik, telah menggunakan GTL paling tidak selama dua minggu, tidak memiliki riwayat penyakit sistemik dan bersedia untuk mengikuti jalannya penelitian dengan menandatangai informed consent.

Sebelum proses penelitian dimulai, semua gigi tiruan dibersihkan dan difoto dengan menggunakan kamera Canon 500D, ukuran lensa $28 \times 135 \mathrm{~mm}$, pencahayaan soft box lightning dan jarak pengambilan foto $20 \mathrm{~cm}$. Pasta pembersih gigi tiruan rosella konsentrasi 2,5\%, yang telah disiapkan sebelumnya diberikan kepada semua sampel. Semua sampel diinstruksikan untuk menggunakan pasta rosella sebagai pembersih gigi tiruan setiap hari.

Bulan ke-3, 6, dan 9 setelah pemakaian pasta, semua sampel dipanggil kembali untuk dilakukan pengambilan foto. Kriteria pengambilan foto sama dengan yang digunakan sebelum pemakian pasta. Hasil foto tersebut lalu dibandingkan dengan pada program Adobe Photoshop versi 7.0. Penilaian warna dilakukan dengan Sistem CIELab.

Terhadap data tersebut selanjutnya dianalisis secarastatistikdengan uji marginal homogenity atau Wilcoxon, kemudian dilakukan pengujian lanjutan dengan uji related sample Friedman two ways untuk menguji hubungan diantara setiap waktu pengujian dengan tingkat kepercayaan $95 \%(p<0,05)$.

\section{HASIL}

Tabel 1 menunjukkan hasil uji statistik dengan Wilcoxon diperolehnilai $>0,05$ pada bulan ke-3 yang berarti tidak ada perbedaan efektivitas pasta rosella terhadap perubahan warna basis gigi tiruan akrilik. Pada bulan ke- 6 dan 9 ditunjukkan bahwa hasil uji statistik padaperubahan warnabasis dengan Wilcoxon diperoleh nilai $\mathrm{P}<0,05$ yang berarti ada perbedaan efektivitas pasta rosella terhadap perubahan warna basis gigi tiruan akrilik dengan nilai $p=0,43$ pada bulan ke- 6 dan nilai $\mathrm{P}=0,43$ pada bulan ke- 9 .

Tabel 1 Hasil pemeriksaan perubahan warna pada gigi tiruan lengkap akrilik sebelum dan setelah pembersihan dengan pasta rosella pada bulan ke- 3,6, dan 9

\begin{tabular}{ccc}
\hline Bulan & $\sum \Delta E^{*} a b$ & $\mathrm{p}$ \\
\hline 3 & $4,14 \pm 2,47$ & 0,080 \\
6 & $7,49 \pm 1,79$ & $0,043^{*}$ \\
9 & $14,56 \pm 1,79$ & $0,043^{*}$ \\
\hline
\end{tabular}

$\alpha<0,05$

\section{PEMBAHASAN}

Penelitian ini menggunakan permukaan intaglio gigi tiruan lengkap. Alasan memilih basis rahang atas karena permukaannya yang cukup luas dibandingkan basis rahang bawah sehingga memudahkan kamera mengambil obyek yang dinilai. Gigi tiruan rahang bawah cenderung memiliki celah yang tidak luas, sehingga ada bagian yang berwarna gelap atau tidak tersorotkamera. Metodeini sejalan dengan penelitian 
serupa mengenai bunga resolla yang sebelumnya telah dilakukan oleh Irfany. ${ }^{5}$

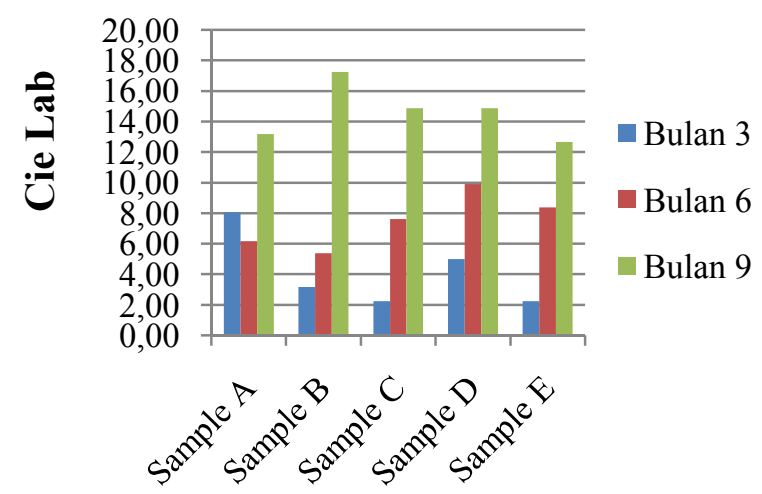

Sampel

Grafik 1 Gambaran hasil pemeriksaan perubahan warna pada gigi tiruan lengkap akrilik sebelum dan setelah pembersihan dengan pasta rosella pada setiap waktu pengujian

Sistem CIELab merupakan model warna yang dirancang untuk menyerupai persepsi penglihatan manusia dengan menggunakan tiga komponen, yaitu $\mathrm{L}^{*}$ sebagai luminance (pencahayaan) dan $\mathrm{a} *$ dan $\mathrm{b}^{*}$ sebagai komponen dimensi warna yang berlawanan. Perancangan sistem aplikasi ini menggunakan sistem CIELab. Model warna ini dipilih karena terbukti memberikan hasil yang lebih baik daripada model warna RGB dalam mengukur nilai kemiripan ciri warna dalam citra. Model warna $L * a * b *$ juga dapat digunakan untuk membuat koreksi keseimbangan warna yang lebih akurat dan untuk mengatur kontras pencahayaan yang sulit dan tidak mungkin dilakukan oleh model warna RGB. ${ }^{6}$

Penggunaan pasta rosella dalam waktu selama tiga bulan sebagai pembersih gigitiruan tidakmemicu terjadinya perubahan warna yang bermakna secara statistik $(p>0,05)$. Akan tetapi pada bulan ke- 6 dan 9 didapatkan bahwa telah terjadi perubahan warna basis gigitiruan jika dibandingkan dengan sebelum pemakaian pasta. Perubahan ini dapat disebabkan oleh antosianin, karena menyebabkan warna merah pada rosella, mengandung delfinidin-3-siloglukosida, delfinidin-3-glukosida, dan sianidin-3-siloglukosida, sedangkan flavonoidnya mengandung gosipetin dan mucilago (rhamnogalaturonan, arabinogalaktan, serta arabinan). ${ }^{7}$ Zat warna merah dari ekstrakbunga rosella sangat berpotensi sebagai pewarna makanan dan minuman, ${ }^{8}$ dan diduga sebagai penyebab terjadinya perubahan warna pada basis gigitiruan.

Temuan ini bertolak belakang dengan hasil yang didapatkan oleh Kamadjaja dkk., yang merendam lempengan akrilik di dalam minuman rosella selama 49 jam yang diestimasikan sebagai pemakaian gigi tiruan selama 2 tahun. Kamadjaja dkk., melakukan penilaian warna dengan sistem spectrometer optic, photocell type BPY-46, danmicrovolt digital. Mereka menyimpulkan bahwa tidak terjadi perubahan warna lempengan akrilik. ${ }^{9}$ Kurniadi, yang juga melakukan penelitian rosella dengan lempeng akrilik juga tidak menemukan terjadinya degradasi warna akrilik.

Perbedaan ini dapat disebabkan karena Kamadjaja dkk, dan Kurniadi melakukan penelitian secara in vitro sedangkan penelitian ini dilakukan secara in vivo. Salah satu sifat resin akrilik adalah menyerap airsecara perlahan-lahan dalamjangka waktu tertentu, dengan mekanisme penyerapan difusi molekul air sesuai dengan hukum difusi. Terjadinya penyerapan zat warna cairan dalam resin akrilik merupakan salah satu faktor penyebab perubahan warna pada resin akrilik. ${ }^{10}$ Rongga mulut merupakan suatu lingkungan yang selalu digenangi oleh cairan saliva. Hal inilah yang dapat menyebabkan terjadinya perbedaan hasil dengan penelitian yang dilakukan oleh Kamadjaja.

Penelitian in vivo yang dilakukan oleh Irfanyjuga bertolak belakang dengan penelitian ini. Penilaian warna yang dilakukanoleh Irfany sama dengan yang diterapkan dalam penelitian ini, yaitu sistem CIELab. Irfany mendapatkan hasil bahwa plat gigi tiruan yang dibersihkan dengan pasta rosella setiap hari selama satu bulan tidak menyebabkan terjadinya perubahan warna yang bermakna secara statistik. ${ }^{5}$ Perbedaan ini dapat disebabkan karena paparan pasta rosella terhadap plat gigi tiruan hanya berlangsung selama 1 bulan, sedangkan dalam penelitian ini berlangsung selama 9 bulan. Paparan zat warna rosella, antosianin, secara terus-menerus dalam jangka waktu yang lama memungkin zat warna ini masuk ke dalam pori-pori yang tercipta akibat sifat porositas mikro akrilik, menyebabkan lempeng akrilik menjadi lebih merah setelah pemakaian pasta setiap hari selama 9 bulan.

Disimpulkanbahwaterjadidegradasi warnabasis gigi tiruanakrilik pasca penggunaan pasta pembersih gigitiruan rosella. Untuk itu, diperlukan penelitian lebih lanjut tentang lama pembersihan gigi tiruan dan intervalnya agar hasilnya tidak merugikan.

\section{DAFTAR PUSTAKA}

1. Carlsson GE, Omar R. Trends in prosthodontic. Med Princ Pract 2006;15:167-79

2. Rathee M, Hooda A, Ghalaut P. Denture hygiene in geriatric persons. Internet J Geriatr Gerontol 2010; 6: 1

3. Maruapey AM. Efektivitas penggunaan pasta pembersih gigitiruan bunga rosella (Hibiscus sabdariffa 1.) dalam menghambat pembentukan plak pada gigitiruan [Tesis]. Makassar: Program Pendidikan Dokter Gigi Spesialis Prostodonsia Fakultas Kedokteran Gigi Universitas Hasanuddin; 2013. p.43-58 
4. Widyanto PS, Nelistya A. Rosella. Jakarta: Penebar Surabaya; 2008

5. Irfani. Stabilitas warna basis akrilik gigitiruan lepasan setelah penggunaan ekstrak dan infusa bunga rosella sebagai pembersih gigitiruan [Tesis]. Makassar: Program Pendidikan Dokter Gigi Spesialis Prostodonsia Fakultas Kedokteran Gigi Universitas Hasanuddin; 2013. p.30-8

6. Optel Vision. Definition of cielab color space. [Serial online] 2011; 1-2: [internet]. Available from URL:http://www. optelvision.com/documents/optel-vision-explanation-on-cielab-color-space.pdf. Diakses tanggal 12 Desember 2012

7. Harmely F, Lucida H, Mukhtar HM. Efektifitas bromelain dari batang nanas (Ananas comosus L.Merr) sebagai antiplak dalam pasta gigi. Scientia 2011; 1(1): 14-9

8. Zarb GA, Bolender CL, Hickey JC, Carlson GE. Buku ajar prostodonti untuk pasien tak bergigi menurut Boucher. Edisi ke-10. Jakarta: EGC; 1987. p.401-3

9. Kamadjaja MJ, Pudjirochani E, W Rhesa A. Effect of immersion in rosella drink for heat cured acrylic color. J Med J Prosthodont 2011: 1

10. Anusavice KJ. Philips: buku ajar ilmu bahan kedokteran gigi. Alih bahasa: Budiman JA, Puwoko S. Jakarta: EGC; 2003. p. 197-218 